\title{
INTERPRETASI SEJARAH SEBAGAI PERISTIWA DAN MASALAH PENDIDIKAN
}

\author{
AHMAD MAKSUM, S.Pd., M. Pd. \\ Staf Pengajar Jurusan PGMI, FTIK IAIN Pontianak
}

When we talk about history, we usually think of the past and interpret it as something insignificant that does not need to be remembered at all. People merely know the events on the surface, but are not aware of the background. For historians and observers of history, an event must be explained further and more in-depth especially about how it happened, as well as social, economic, political, and cultural backgrounds. Simply recounting an event does not completely explain it, because historians are professional travelers in the world of the past. In the academic context, history is a field of science or study that requires a critical historical imagination in its analysis. This is intended to place history in its phenomenological setting. History is not only about the "past events", but it is also related to current events. The role of historians is very strategic especially in changing society's idea which should start from the concept of learning at school or college.

In this light, historians and history teachers should be able to see through the mind of historical actors by trying to revive the thoughts of the historical actors in his/her own mind; in other words, historians should be able to put themselves into the shoes of the actors in history. It is considered an essential element in the "historical thinking" which serves as the basis of historical explanation.

History as an autonomous discipline needs to be developed in accordance with the pattern of the tendency of history itself. Conventional historical writing only tells the story of history in a descriptive-narrative form, simply explaining how an event occurs and does not touch its focal point. To get a more complete picture of the reality, people need to approach historical events from various aspects better known as a multidimensional approach, and it certainly requires a multidisciplinary method called an interdisciplinary method.

Keywords: history, historical thinking, interdisciplinary method, multidimensional approach

\section{PENGANTAR}

Ketika berbicara mengenai sejarah, acapkali yang terbayang adalah masa lampau dan tidak sedikit mengartikannya sebagai sesuatu yang tak perlu diingat secara totalitas dan tidak meaningfull. Stigma ini mungkin ada benarnya, tetapi perlu diperhatikan sejarah seperti apa yang termasuk pada stigma itu, karena tentu saja sejarah bukan saja berisi rentetan kejadian biasa, tetapi juga kejadian luar biasa (peristiwa) yang masih meninggalkan jejak yang bisa direkonstruksi untuk kemudian dimaknakan secara jernih pada masa kini. Dalam konteks filsafat sejarah, sesungguhnya terjadi komunikasi yang tak pernah berhenti antar dimensi lampau, sekarang, dan yang akan datang. Akan tetapi dimensi-dimensi tersebut nyaris tak dirasakan ek- 
sistensinya oleh manusia, padahal di sisi lain manusia sangat haus dengan masa lalu terutama pada saat akan mengambil atau menentukan keputusan penting pada masa sekarang. Kemudian keputusan sekarang diproyeksikan untuk masa yang akan datang. Jika berpegang pada hal tersebut, maka tak berlebihan kiranya Cicero mengatakan history make a wise, atau seruan Soekarno dengan jasmerah (jangan sekali-kali melupakan sejarah).

Orang hanya mengenal peristiwa-peristiwa di permukaan, tetapi tidak mengetahui apa yang memungkinkan peristiwa-peristiwa itu terjadi. Bagi kalangan sejarawan dan pemerhati sejarah, suatu peristiwa harus diterangkan secara lebih jauh dan lebih mendalam mengenai bagaimana terjadinya, latar belakang kondisi sosial, ekonomi, politik, dan juga kulturalnya. Hanya menceritakan bagaimana terjadinya suatu peristiwa, belum memberikan eksplanasi secara tuntas dan lengkap, karena sejarawan adalah wisatawan professional dalam dunia lampau (Sartono Kartodirdjo, 1992: 27). Oleh karena itu, sejarawan sejatinya harus mampu menunjukkan pola-pola perkembangan, konteks dan kondisi peristiwa, serta akibatnya, yang kesemuanya sukar diketahui dan dipahami oleh semua orang yang tidak mengalami sendiri peristiwa-peristiwa itu.

Walaupun sejarawan pada umumnya termotivasi oleh rasa cintanya pada masa lampau dengan segala keunkannya serta oleh hasratnya untuk mendapatkan pengetahuan yang lebih kongkret tentang peristiwa, pelaku, dan situasi sejarah, hasil kerjanya pada dasarnya ditujukan kepada orang-orang dari masanya sendiri. Perhatiannya terhadap masa lampau, terutama pada periode yang ditandai oleh perubahan yang pesat dan revolusioner, ketidakpastian yang bersifat konstan, krisis, terkait dan sebanding dengan keterlibatan emosional mereka dengan masa kini dan dengan pencarian mereka akan berbagai jawaban terhadap fenomena dan soal-soal yang melingkupi mereka (Soedjatmoko, dkk., 1995: 385).

\section{SEJARAWAN : "HAKIM" MASA LAMPAU}

Dalam konteks akademis, sejarah merupakan suatu bidang ilmu atau bidang studi yang memerlukan imajinasi kesejarahan yang kritis dalam pengkajiannya. Hal ini menurut Suyatno Kartodirdjo (2000: 31) dimaksudkan untuk menempatkan sejarah dalam setting historis yang fenomenologis. Sejarah tidak selalu menyangkut "past event" atau peristiwa-peristiwa masa lampau, tetapi juga berhubungan atau menyangkut peristiwa-peristiwa mutakhir (current events). Dalam konteks ini, sejarawan yang bertindak sebagai duta dari masa lampau tidak hanya memberikan informasi tentang negeri pada jaman tertentu, tetapi juga kondisi dan situasinya, sistem ekonomi, sosial, dan politik, serta seluruh fenomena kehidupan masyarakat dalam berbagai aspeknya.

Dengan berbagai pendekatan dalam metodenya, sejarawan menjalankan tugasnya dalam berbagai lapangan. Hasilnya dapat memperdalam pengertian dibidang politik, ekonomi, sosial, dan kebudayaan. Bagi seorang sejarawan sangatlah penting untuk menyadari bahwa, wujud dan isi cita-cita serta nilai-nilai bangsanya tidak bisa dimengerti tanpa refleksi kepada sejarah dan pengalaman bangsa itu. Oleh sebab itu, kesadaran sejarah merupakan orientasi intelektual, suatu sikap jiwa yang perlu untuk memahami secara tepat paham kepribadian nasional (Sartono Kartodirdjo, 1990: 63).

Kesadaran sejarah sangat diperlukan sebagai suatu cara untuk melihat realitas sosial dengan segala permasalahannya 
bukan saja sebagai masalah-masalah moral yang memerlukan jawaban ya atau tidak, putih atau hitam, melainkan agar manusia mampu melihat masalah-masalah dinamika sosial termasuk segi moralnya, sebagai suatu masalah-masalah historis yang memerlukan cara-cara penghadapan historis pula (Soedjatmoko, 1983: 69).

Sejarawan harus bisa menjangkau bagian dalam peristiwa sejarah atau pikiranpikiran yang melatarbelakanginya. Dalam konteks ini Collingwood menekankan keistimewaan yang dapat dilakukan oleh sejarawan terhadap objeknya yaitu dengan jalan be thingking them in his own mind (memikirkan kembali dalam pikiran sejarawan sendiri).

Dengan ini, sejarawan harus mampu meneropong pikiran pelaku sejarah dengan cara mencoba menghidupkan kembali pikiran-pikiran pelaku sejarah tersebut dalam pikirannya sendiri; dengan kata lain secara imajiner sejarawan harus mencoba menempatkan dirinya ke dalam pelaku-pelaku sejarah yang bersangkutan. Ini dianggap merupakan unsur pokok dalam "cara berpikir historis" (historical thingking) yang menjadi dasar dari "cara menerangkan dalam sejarah"

\section{(historical explanation).}

Dengan demikian sejarawan dianggap perlu memperhatikan prinsip koligasi dalam menerangkan peristiwa yaitu suatu prosedur menerangkan suatu peristiwa dengan jalan menelusuri hubungan-hubungan instrinsiknya dengan peristiwa-peristiwa lainnya dan menentukan tempatnya dalam keseluruhan peristiwa sejarah (I Gede Widja, 1989: 123). Dengan demikian, akan dapat ditentukan langkah nyata untuk memajukan usaha merekonstruksikan sejarah.

Dengan pengetahuan masa lampau yang benar dan kongkret, akan dapat diwu- judkan identitas sejarah. Usaha untuk mencari relevansi dapat diartikan bahwa sejarah harus menjadi bagian dari pengetahuan kolektif yang mampu menjelaskan kesinambungan dan perubahan masyarakat untuk kepentingan pembangunan. Jelaslah bahwa penulisan sejarah, dewasa ini tidak dapat dipisahkan dari kebudayaan masa kini beserta masalah-masalahnya baik dalam bidang politik maupun dalam lapangan ekonomi atau sosial (William H. Frederick dan Soeri Soeroto, 1982: 66).

Sejarah sebagai disiplin ilmu yang otonom, perlu dikembangkan menurut pola kecenderungan ilmu sejarah itu sendiri. Penulisan sejarah konvensional, yang menyusun ceritera sejarah secara deskriptif-naratif belaka, hanya menerangkan bagaimana suatu peristiwa terjadai, dan tidak menyentuh substansinya. Supaya mendapat gambaran yang lebih lengkap mengenai realitas tersebut, orang perlu mendekati peristiwa sejarah dari berbagai segi, yang disebut pendekatan multidimensional dan sudah barang tentu memerlukan metode dari berbagai ilmu yang disebut metode Interdisipliner (Sartono Kartodirdjo, 1982: 66). Dalam konsep ini metodologinya telah disempurnakan untuk menggarap berbagai permasalahan yang kompleks.

Dengan meminjam konsep dan teori dari imu-ilmu sosial yang lain, alat analitik dan kerangka konseptualnya menjadi sempurna. Bukti dari itu semua adanya pertumbuhan produksi yang besar dalam penulisan sejarah (Sartono Kartodirdjo, 1990: 193).

\section{SEJARAH YANG BIJAKSANA}

Sementara itu orang bertanya apakah sejarah itu perlu. Untuk membahas dan menjawab pertanyaan ini, perlulah kiranya historiskritis menelaahnya dari diakronisme ilmu sejarah itu. Orang tidak akan belajar se- 
jarah jika tidak ada manfaatnya. Kenyataan bahwa sejarah terus ditulis orang disemua peradaban dan disepanjang waktu, sebenarnya cukup menjadi bukti bahwa sejarah itu perlu (Kuntowijoyo, 1995: 19).

Sejarah merupakan suatu penalaran kritis dan kerja yang cermat untuk mencari kebenaran; suatu penjelasan yang cerdas tentang sebab-sebab dan asal-usul segala sesuatu; suatu pengetahuan yang mendalam tentang bagaimana dan mengapa peristiwa-peristiwa itu terjadi. Sejarah dapat mengajar man of action (manusia pelaku) tentang bagaimana orang lain bertindak dalam keadaan-keadaan khusus, piihan-pilihan yang dibuatnya, dan tentang keberhasilan dan kegagalan mereka. Tanpa mengenal sejarah, seseorang akan kehilangan arah dan acuan dalam melaksanakan kebijaksanaannya.

Karena sejarah adalah jembatan penghubung masa silam dan masa kini, dan sebagai petunjuk arah ke masa depan (Ahmad Syafii Maarif, 1997: 4). Sejarah tidak hanya sekedar serangkaian peristiwa yang mandek dan hanya menjadi ceritera pelipur lara, ceritera pembangkit semangat untuk "kebesaran diri”, melainkan lebih dari itu, bahwa sejarah terjadi di dalam "suatu lingkaran waktu yang satu", yang selalu bergerak tanpa henti. Oleh karena itu, waktu dapat dikatakan selalu berada di dalam kekinian.

Dalam kekiniannya yang selalu bergerak itulah waktu dapat terbagi menjadi tiga masa: yaitu waktu kini, masa lampau, waktu kini sekarang, dan waktu kini yang akan datang (Anhar Gonggong, 1996: 4). Sejarah sebagai bagian masa dari gerak waktu tanpa henti, memiliki dinamika yang menggerakkan. Generasi yang hidup dalam "waktu kini-sekarang" mempunyai kedudukan strategis.

Kedudukan strategis yang dimaksud adalah generasi dalam "waktu kini sekarang”, adalah membangun kelangsungan hidup dirinya dengan mengacu kepada "waktu kinimasa lampau" dan sekaligus berperan dalam merancang kehidupan generasi yang hidup di dalam "waktu kini-yang akan datang".

\section{SEJARAH : ILMU ATAU SENI}

Dalam kajian ilmiahnya, muncullah kontropersi apakah sejarah itu sebagai ilmu atau seni. Mungkin pendirian moderat yang mengatakan bahwa, sejarah mengandung kedua dimensi ilmu dan seni pantas untuk dipertahankan. Dari sudut metode pengumpulan dan penafsiran data, sejarah tidak berbeda dengan metode ilmu pada umumnya (Juliet Gardiner, 1988: 69-72). Tetapi dalam teknik penyusunan laporan, unsur imajinasi sejarawan memegang peranan penting, dan tentu saja bukanlah imajinasi liar.

Imajinasi historis adalah imajinasi yang dikontrol oleh hukum-hukum logika berdasarkan fakta. Karena imajinasi inilah karya sejarah dirasakan juga sebagai karya sastra. Kemudian dalam masalah bahasa, bahasa sejarah lebih dekat kepada bahasa novel daripada bahasa teks ilmiah. Hal ini memang diperlukan, sebab bila tidak, siapa yang akan betah membaca karya sejarah. Sekalipun demikian, laporan sejarah senantiasa menuntut akurasi dalam bingkai disiplin historis.

Tinggi rendahnya kualitas sebuah karya sejarah akan sangat tergantung kepada akurasi dan disiplin seorang sejarawan dalam membangun laporannya. Dalam historiografi, dikenal istilah sejarah yang baik dan sejarah yang papa (poor history). Yang paling repot adalah "sejarah yang terburuk sekalipun tetaplah ia sejarah” (G. J. Renier, 1995: 22).

\section{PROBLEM PENDIDIKAN SEJARAH}

Dalam konteks filosofis, sejarah dan 
pendidikan pada dasarnya merupakan suatu kesatuan yang utuh dan menyeluruh. Pendidikan merupakan pembagian dari sejarah. Fenomena ini dapat dimafhumi karena sejarah berdimensi tiga waktu, yakni masa lalu untuk dapat membicarakan masa kini, dan masa kini untuk masa depan. Kepentingan terhadap masa lalu itu adalah mengungkapkan significance dan menerangkannya sesuai dengan kesadaran struktural, imajinasi kesejarahan, serta menghapus cara berfikir anakronistik, yaitu cara berpikir yang mencampuradukkan dimensi waktu yang berbeda-beda dalam suatu penyederhanaan (Taufik Abdullah, 1996: 7).

Sementara itu pendidikan memiliki kadar relevansi dalam kehidupan. Pendidikan sejarah menyeimbangkan aspek kuantitas dan kualitas bahannya, menyajikan bahan mendalam dengan maksud memudahkan internalisasi nilai yang terkandung dalam bahan tersebut (Husain Haikal, 1989: 8). Untuk mengemas pendidikan sejarah sehingga dapat menghasilkan internalisasi nilai, diperlukan adanya pengorganisasian bahan yang beraneka ragam serta metode sajian yang bervariasi.

Disamping itu gaya belajar subjek-didik juga perlu mendapat perhatian, agar tidak kehilangan bingkai moral dan afeksi dari seluruh tujuan pengajaran yang telah ada. Karena tanpa bingkai moral, pengajaran sejarah yang terlalu mengedepankan aspek kognitif tidak akan banyak pengaruhnya dalam rangka memantapkan apa yang sering disebut sebagai jati diri kepribadian bangsa. Untuk itu para pengajar sejarah ataupun para peminat sejarah harus mempunyai wawasan yang luas dan mendalam tentang hakekat suatu sejarah, sehingga tujuan pendidikan secara substansial dapat tercapai.

Dalam dinamika kehidupan masyarakat yang serba berubah, menuntut suatu perubahan dalam kurikulum pendidikannya (Allan C. Ornstein and Daniel U Levine, 1996). Pendidikan sejarah merupakan bagian integral dari usaha penanaman nilai-nilai yang fungsional untuk menanamkan pengetahuan. Dalam pengembangan kurikulum pendidikan sejarah, perlu dilakukan sesuai dengan kriteria yang dikembangkan yang sesuai dengan ciri-ciri fleksibelitas realistik, dan berorientasi pada kepentingan ke depan (Hafid Abbas, 1998: 85).

Dalam kaitan ini, pendidikan sejarah perlu mentransfer nilai-nilai etik dan moral yang mendasari cara berpikir, cara bersikap, dan berprilaku seseorang untuk mewujudkan keharmonisan kehidupan individu, kelompok masyarakat atau bangsa dalam membangun perdamaian, toleransi dan kesediaan menerima perbedaan. Jika ditinjau dari segi kurikulum yang terakhir, pengajaran sejarah di Indonesia mempunyai kedudukan yang cukup pasti.

Kurikulum pendidikan sejarah diperguruan tinggi telah menggariskan dan mengarahkan peserta didik untuk berpikir konprehensif dan kritis. Tetapi, akhir-akhir ini tampaknya pengajaran sejarah yang dilaksanakan diberbagai jenjang pendidikan tinggi memberi kesan yang kuat hanya bersifat kognitif dan cenderung bersifat hafalan. Pendidikan sejarah dilakukan secara terisolasi dari kenyataan kekinian.

Dalam hal ini setidaknya ada empat komponen yang saling berkait yang menjadi penyebab mengapa pengajaran sejarah itu tidak atau kurang efektif. Pertama, adalah komponen tenaga pengajar sejarah yang pada umumnya miskin wawasan kesejarahan. Salah satu penyebab utama dari kemiskinan wawasan ini adalah kemalasan intelektual untuk menggali sumber sejarah, baik yang berupa benda-benda, dokumen, maupun literatur, 
pengajar sejarah harus kaya informasi, tidak saja tentang masa lampau yang sarat dengan berbagai tafsiran, tetapi juga tentang masa kini yang penuh dinamika dan serba kemungkinan, konstruktif maupun destruktif (Ahmad Syafii Maarif, 1995: 9).

Pengajar sejarah yang baik adalah mereka yang mampu merangsang dan mengembangkan daya imajinasi peserta didik sedemikian rupa hingga cerita sejarah yang disajikan, dirasakan senantiasa menantang rasa ingin tahu. Karena sejarah adalah panorama kehidupan yang penuh warna.

Kedua, adalah komponen peserta didik. Sikap maupun persepsi yang kurang positif peserta didik terhadap pengajaran sejarah, akan sangat berpengaruh terhadap hasil tujuan pembelajaran. Tidak sedikit peserta didik yang hanya mengejar nilai dan popularitas, untuk kegunaan sesaat. Padahal substansi yang sesungguhnya adalah khasanah keilmuan yang ia pelajari untuk dikembangkan dan diterapkan dalam kehidupan sehari-hari, sehingga nilai-nilai yang terkandung di dalamnya dapat diinternalisasikan. Sejarah adalah guru kebijaksanaan yang sejati.

Ketiga, adalah metode pengajaran sejarah yang pada umumnya kurang menantang daya intelektual peserta didik. Untuk melibatkan subjek-didik dalam tataran intelektual dan emosional dalam pengajaran sejarah adalah barang tentu bukan jamannya lagi dengan menggunakan metode dongeng yang diselimuti oleh berbagai peristiwa ajaib, mistis, dan supranatural. Kalau metode itu yang digunakan justru bertentangan dengan tujuan pengajaran sejarah itu sendiri. Memang dengan menggunakan metode dongeng peserta didik banyak yang tertarik, tetapi metode itu justru tidak menjadikan dirinya sebagai sosok manusia yang menyejarah, karena menganggap bahwa berbagai pengaruh sejarah berada di luar dirinya.

Keempat, adalah komponen bukubuku sejarah dan media pengajaran sejarah. Untuk sejarah Indonesia, telah ada sejarah nasional yang jumlahnya enam jilid. Buku itu sebenarnya dapat menolong, sekalipun di sana sini masih ada celahnya yang perlu dilengkapi dengan sumber-sumber lain. Tetapi pendekatan yang terlalu Indonesia-sentris seperti yang terdapat dalam buku sejarah nasional itu, harus disikapi secara hati-hati. Pendekatan itu dapat menimbulkan kecenderungan "memberhalakan" masa lampau suatu bangsa. Apalagi bila anyaman masa lampau itu sarat oleh mitos yang bisa saja melumpuhkan daya kritis peserta didik. Sebenarnya buku-buku teks lainnya telah bermunculan, tetapi hampir-hampir tidak ada yang menggunakan pendekatan moral-saintifik terhadap perjalanan sejarah bangsa.

Dalam pada itu, literatur tentang sejarah umum masih amat sedikit, padahal fungsinya sangat penting. Sejarah nasional khususnya dianggap mempunyai nilai didaktif-edukatif bagi pembentukan jati diri bangsa dan pemersatu berdasarkan atas pengalaman kolektif bernegara dan berbangsa (Ahmad Syafii Maarif, 1995: 9).

\section{PEMECAHAN PROBLEM PENDIDIKAN SEJARAH}

Bangsa Indonesia adalah bangsa yang besar, heterogen, plural, dan memiliki karakteristik masyarakat yang berbeda-beda. Ini merupakan ciri khas bangsa Indonesia sebagai bangsa yang majemuk. Dalam perjalanan sejarah panjangnya, dinamika bangsa ini belum mencapai tingkat yang signifikan, jika dibandingkan dengan Negara-negara Asia sekalipun seperti Malaysia, Singapura, Jepang, dan lain sebagainya.

Sebenarnya, kemajemukkan bangsa 
ini merupakan modal yang sangat potensial untuk memupuk persatuan dan kesatuan, dan dalam rangka memperkokoh integritas dan kepribadian bangsa. Tetapi jika modal yang besar itu tidak disikapi secara positif oleh komponen bangsa ini, maka justru akan mengakibatkan hal yang sebaliknya, akan menjadi bom waktu yang mengerikan, dimana setiap saat akan menimbulkan ledakan hebat yang mengakibatkan tercerabutnya integrasi bangsa ini.

Pada saat bangsa Indonesia menghadapi setumpuk permasalahan yang disebabkan oleh berbagai krisis yang melanda, maka tantangan dalam menghadapi suatu era globalisasi yang bercirikan keterbukaan dan persaingan bebas kian mendesak. Mau tidak mau bangsa Indonesia harus berupaya keras untuk meningkatkan kemampuan dan daya saing sumber daya manusianya dalam percaturan internasioanal.

Dalam jangka waktu yang relative mendesak Indonesia harus mampu mempersiapkan sumber daya manusia yang professional, tangguh, dan siap pakai. Untuk mewujudkan kondisi tersebut, sumber daya manusia Indonesia perlu memiliki bekal kemampuan intelektual dan daya pikir serta daya inovasi yang tinggi, juga memiliki pengetahuan, dan kebiasaan menerapkan sikap moral yang baik. Cara-cara berpikir baru dan terobosan-terobosan baru harus diperkenalkan dan diciptakan untuk mengatasi permasalahan pendidikan pada masa sekarang dan masa yang akan datang.

Dengan kata lain, reformasi pendidikan dengan berbagia segmen-segmennya merupakan suatu kebutuhan dan juga suatu imperative action (Zamroni, 2000: 158). Sistem pengajaran sebagai bagian integral dari sistem kegiatan pendidikan, merupakan fenomena yang harus diperbaiki dan dikem- bangkan oleh pihak-pihak yang terkait dan berkepentingan. Hal ini menyangkut kurikulum, metode, media pengajaran, materi pengajaran, kualitas guru, dan lain sebagainya sehingga tercipta sistem pengajaran yang baik dan berorientasi ke masa depan.

Dengan demikian perlu dikembangkan prinsip-prinsip belajar yang berorientasi pada masa depan, dan menjadikan peserta didik tidak hanya sebagai objek belajar tetapi juga subjek dalam belajar. Pendidikan tidak lagi berpusat pada lembaga atau guru yang hanya akan mencetak para lulusan yang kurang berkualitas, melainkan harus berpusat pada siswa sebagai pusat belajar, yang tidak hanya "disuapi" dengan materi pengajaran, tetapi juga harus memberikan kesempatan kepada para siswa untuk bersikap kreatif dan mengembangkan diri sesuai dengan potensi intelektual yang dimilikinya. Sistem pengajaran yang baik seharusnya dapat membantu mencapai tujuan-tujuan belajarnya.

Meskipun proses belajar mengajar tidak dapat sepenuhnya berpusat pada siswa seperti pada pendidikan terbuka, tetapi yang perlu dicermati adalah bahwa pada hakekatnya siswalah yang harus belajar dan mengembangkan diri. Dengan demikian proses belajar mengajar perlu berorientasi pada kebutuhan dan kemampuan siswa. Kegiatan-kegiatan yang dilakukan dalam proses belajar mengajar harus dapat memberikan pengalaman belajar yang menyenangkan dan berguna bagi siswa. Guru perlu memberikan bermacam-macam situasi belajar yang memadai untuk materi yang disajikan, dan menyesuaikannya dengan kemampuan serta karakteristik siswa sebagai subjek-didik.

Mengajar merupakan suatu aktivitas professional yang memerlukan keterampilan tingkat tinggi dan mencakup hal-hal yang berkaitan dengan pengambilan keputu- 
san-keputusan (Winata Putera, 1992: 86). Sekarang ini guru lebih dituntut untuk berfungsi sebagai pengelola proses belajar mengajar yang melaksanakan tugas yaitu dalam merencanakan, mengatur, mengarahkan, dan mengevaluasi. Keberhasilan dalam belajar mengajar sangat tergantung pada kemampuan guru dalam merencanakan, yang mencakup antara lain menentukan tujuan belajar siswa, bagaimana caranya agar siswa mencapai tujuan tersebut, sarana apa yang diperlukan, dan lain sebagainya.

Dalam hal mengatur, yang dilakukan pada waktu iplementasi apa yang telah direncanakan dan mencakup pengetahuan tentang bentuk dan macam kegiatan yang harus dilaksanakan, bagaimana semua komponen dapat bekerja sama dalam mencapai tujuan-tujuan yang telah ditentukan. Guru bertugas untuk mengarahkan, memberikan motivasi, dan memberikan inspirasi kepada siswa untuk belajar. Memang benar tanpa pengarahanpun masih dapat juga terjadi proses belajar, tetapi dengan adanya pengarahan yang baik dari guru maka proses belajar dapat berjalan dengan lancar.

Sedangkan dalam hal mengevaluasi, termasuk penilaian akhir, hal ini dimaksudkan apakah perencanaan, pengaturan, dan pengarahannya dapat berjalan dengan baik atau masih perlu diperbaiki. Dalam proses belajar mengajar, guru perlu mengadakan keputusan-keputusan, misalnya metode apakah yang perlu dipakai untuk mengajar mata pelajaran tertentu, alat dan media apakah yang diperlukan untuk membantu siswa membuat suatu catatan, melakukan praktikum, menyusun makalah diskusi, atau cukup dengan hanya mendengar ceramah guru saja. Dalam proses belajar mengajar guru selalu dihadapkan pada bagaimana melakukannya, dan mengapa hal tersebut perlu dilakukan.
Begitu juga dalam hal evaluasi atau penilaian dihadapkan pada bagaimana sistem penilaian yang digunakan, bagaimana kriterianya, dan bagaimanapula kondisi siswa sebagai subjek belajar yang memerlukan nilai itu.

Dalam rangka pengembangan pengajaran sejarah agar lebih fungsional dan terintegrasi dengan berbagai bidang keilmuan lainnya, maka terdapat berbagai bidang yang seyogianya mendapat perhatian.

Pertama, untuk menjawab tantangan masa depan, kreativitas dan daya inovatif diperlukan agar bangsa Indonesia bukan sekedar menjadi konsumen IPTEK, konsumen budaya, maupun penerima nilai-nilai dari luar secara pasif, melainkan memiliki keunggulan komparatif dalam hal penguasaan IPTEK. Oleh karenanya, kreativitas perlu dikembangkan melalui penciptaan situasi proses belajar mengajar yang kondusif dimana guru mendorong vitalitas dan kreatifitas siswa untuk mengembangkan diri. Siswa perlu diberi kesempatan untuk belajar dengan daya intelektualnya sendiri, melalui proses rangsangan-rangsangan baik yang berupa pertanyaan-pertanyaan maupun penguasaan, sehingga siswa dapat melihat suatu hal dari berbagai sudut pandang dan dapat menemukan berbagai alternatife pemecahan masalah yang dihadapi.

Kedua, siswa akan dapat mengembangkan daya kreatifitasnya apabila proses belajar mengajar dilaksanakan secara terencana untuk meningkatkan dan membangkitkan upaya untuk kompetitif. Oleh karena itu, proses belajar mengajar yang memberi peluang kepada siswa untuk menyelesaikan tugas secara kompetitif perlu disosialisasikan, kemudian juga perlu adanya penghargaan yang layak kepada mereka yang berprestasi. Hal ini akan berdampak positif terhadap terbentuknya rasa percaya diri pada siswa. Pada 
gilirannya, pengalaman ini selanjutnya dapat menjaga proses pembentukan kemandirian. Dalam hal ini siswa juga perlu dilibatkan dalam proses belajar mengajar yang memberikan pengalaman bagaimana siswa bekerja sama dengan siswa yang lain seperti dalam hal berdiskusi, membuat artikel kelompok, pengamatan, wawancara, dan sebagainya untuk dikerjakan secara kelompok. Pengalaman belajar seperti ini selanjutnya akan dapat membentuk sikap kooperatif dan ketahanan bersaing dengan pengalaman nyata untuk dapat menghargai segala kelebihan dan kelemahan masing-masing.

Ketiga, dalam proses pengembangan kematangan intelektualnya, siswa perlu dipacu kemampuan berfikirnya secara logis dan sistematis. Dalam proses belajar mengajar, guru harus memberi arahan yang jelas agar siswa dapat memecahkan suatu persoalan secara logis dan ilmiah. Oleh karena itu, siswa perlu dilibatkan secara aktif dalam proses belajar mengajar melalui pemberian tugas. Tugas tidak terlalu berat tetapi dapat memacu daya berfikir siswa. Salah satu aspek yang penting adalah bagaimana siswa dapat terlatih berfikir secara deduktif-induktif. Artinya, dalam proses belajar mengajar siswa perlu diarahkan sedemikian rupa sehingga siswa dapat mempelajari materi pelajaran melalui pengalaman. Dengan cara seperti ini mereka dapat secara langsung dihadapkan pada suatu realita dilapangan. Seperti halnya siswa disediakan mata pelajaran yang bersifat khusus yang memberikan pengalaman, berdiskusi, penelitian, dan lain sebagainya yang diarahkan untuk menarik kesimpulan baik deduktif maupun induktif.

Keempat, siswa harus diberi internalisasi dan keteladanan, dimana siswa dapat berperan aktif dalam kegiatan belajar mengajar. Fenomena ini dalam hal-hal tertentu dapat membentuk semangat loyalitas, toleransi, dan kemampuan adaptasi yang tinggi. Dalam hal pendekatan ini perlu diselaraskan dengan kegiatan proses belajar mengajar yang memberi peluang kepada mereka untuk berprakarsa secara dinamis dan kreatif. Dengan demikian akan tercapai kualitas proses dan hasil belajar yang berorientasi pada pencapaian tujuan yang jelas, dengan melibatkan siswa secara maksimal melalui berbagai kegiatan yang konstruktif, sehingga pengalaman tersebut dapat mengantar siswa dalam suatu proses belajar yang kondusif dan kreatif.

\section{HAKEKAT PENDIDIKAN SEJARAH}

Pengajaran sejarah sebagai sub-sistem dari sistem kegiatan pendidikan, merupakan sarana yang efektif untuk meningkatkan integritas dan kepribadian bangsa melalui proses belajar mengajar. Keberhasilan ini akan ditopang oleh berbagai komponen, termasuk persepsi guru yang positif terhadap pengajaran sejarah dengan kurikulum baru. Sistem kegiatan pendidikan dan pengajaran adalah sistem kemasyarakatan yang kompleks, diletakkan sebagai suatu usaha bersama untuk memenuhi kebutuhan pendidikan dalam rangka untuk membangun dan mengembangkan diri (Banathy, Bela H., 1992: 175).

Dalam konteks yang lebih sederhana, pengajaran sejarah sebagai sub sistem dari sistem kegiatan pendidikan, merupakan usaha pembandingan dalam kegiatan belajar, yang menunjuk pada pengaturan dan pengorganisasian lingkungan belajar mengajar sehingga mendorong serta menumbuhkan motivasi peserta didik untuk belajar dan mengembangkan diri. Di dalam pengajaran sejarah, masih banyak kiranya hal yang perlu dibenahi, misalnya tentang porsi pengajaran sejarah yang berasal dari ranah kognitif dan afektif. Kedua ranah tersebut harus selalu ada 
dalam pengajaran sejarah. Pengajaran sejarah yang mengutamakan fakta keras, kiranya perlu mendapat perhatian yang signifikan karena pengajaran sejarah yang demikian hanya akan menimbulkan rasa bosan dikalangan peserta didik dan pada gilirannya akan menimbulkan keengganan untuk mempelajari sejarah (Soedjatmoko, 67).

Apabila sudah disadari hubungan erat antara sejarah dengan pendidikan, memang belum ada jaminan bahwa makna dasar dari sejarah telah bisa diwujudkan untuk menunjang proses pendidikan itu. Masih diperlukan proses aktualisasi nilai-nilai sejarah dalam kehidupan yang nyata. Dengan kata lain, sejarah tidak akan berfungsi bagi proses pendidikan yang menjurus ke arah pertumbuhan dan perkembangan karakter bangsa apabila nilai-nilai sejarah tersebut belum terwujud dalam pola-pola perilaku yang nyata.

Menurut Dennis Gunning, secara umum pengajaran sejarah bertujuan untuk membentuk warga negara yang baik, dan menyadarkan peserta didik untuk mengenal diri dan lingkungannya, serta memberikan perspektif historikalitas. Sedangkan secara spesifik, lanjut Gunning, tujuan pengajaran sejarah ada tiga yaitu, mengajarkan konsep, mengajarkan keterampilan intelektual, dan memberikan informasi kepada peserta didik (Gunning Dennis, 1978: 179-180). Dengan demikan, pengajaran sejarah tidak bertujuan untuk menghafal berbagai peristiwa sejarah.

Keterangan tentang kejadian dan peristiwa sejarah hanyalah merupakan suatu tujuan. Sudah barang tentu tujuan disini dikaitkan dengan arah baru pendidikan modern, yaitu menjadikan peserta didik mampu mengaktualisasikan diri sesuai dengan potensi dirinya dan menyadari keberadaannya untuk ikut serta dalam menentukan masa depan yang lebih manusiawi bersama-sama dengan orang lain. Dengan kata lain adalah berupaya untuk menyadarkan peserta didik akan historikalisasi diri dan masyarakatnya. Tujuan yang telah ditetapkan sesuai dengan kondisi yang ada sangat mungkin untuk tercapai karena seorang pengajar sejarah sebagai organisator dan fasilitator menempati posisi yang strategis dalam proses belajar mengajar.

Posisi strategis seorang pengajar sejarah sebaiknya disertai dengan kemampuan atau kompetensi yang memadai, seperti mampu mengenal setiap peserta didik yang dipercayakan kepadanya, memiliki kecakapan memberi bimbingan, memiliki pengetahuan yang luas mengenai bidang ilmu yang diajarkan, dan mampu memilih strategi belajar mengajar secara tepat (Winarno Surakhmad, 2000: 14). Menurut Preire, yang paling penting adalah bahwa pendidikan termasuk pengajar sejarah haruslah berorientasi kepada pengenalan realitas diri manusia dan dirinya sendiri (Freirre, Paulo, 1999: 9).

Tujuan pendidikan sejarah tersebut memang harus melalui suatu proses, dimana dalam proses itulah yang tidak jarang menjadikan pendidik sejarah dalam proses belajar mengajarnya hanya terkungkung oleh berbagai perubahan pragmatis. Maka seiring dijumpai adanya pengajaran sejarah yang mengutamakan pada hafalan materi sejarah, karena yang dikejar adalah materinya itu sendiri. Pengajar sejarah yang demikian itu sebenarnya telah terperangkap pada bidang gelap, karena tidak mampu menjangkau sesuatu yang ingin dicapainya.

Fenomena itu muncul karena adanya kekuatan atau perangkap yang secara tidak kentara tetapi pasti menjebak pengajar sejarah, seperti adanya birokratisasi dalam pengajaran, mekanisme tes yang seragam dan mengutamakan ranah kognitif, target penyelesaian pengajaran sesuai dengan yang tercan- 
tum dalam kurikulum, dan lain sebagainya. Menghadapi berbagai hal tersebut menjadikan sebagian besar pengajar sejarah berada dalam suatu fellings of powerlessness (rasa tak berdaya) menghadapi dunianya. Apalagi masih adanya kecenderungan dari kelompok yang dominan yang lebih menekankan pada stabilitas, maka kajian materi sejarah secara kritis dan kreatif hanya dirasakan sebagai utopia belaka. Dalam konteks yang demikian itu barangkali perlu suatu pendekatan struktural, yang menekankan pada aspek sistem dalam mempengaruhi kesadaran individu. Pengajaran sejarah hendaknya diselenggarakan sebagai suatu avontuur bersama dari pengajar dan yang diajar.

Dalam konsep ini, maka bukan hafalan fakta, melainkan riset bersama antara pengajar dan peserta didik menjadi model utama. Dengan jalan ini, maka peserta didik langsung dihadapkan dengan tantangan intelektual yang memang merupakan ciri khas dari sejarah sebagai ilmu. Demikian juga dilibatkan secara langsung pada suatu engagement baru dalam arti sejarah untuk hari ini (Soedjatmoko, 7: 67). Meskipun metode yang diajukan tersebut cukup baik, namun pengajar sejarah yang hendak mencobanya perlu mempertimbangkan akan kegagalan atau keberhasilannya.

Dengan kata lain, suatu metode yang dipilih harus selalu dipertimbangkan segi efektifitas dan efisiensinya. Keterlibatan peserta didik secara lebih aktif merupakan kecenderungan baru dalam proses belajar mengajar. Kecenderungan semacam ini mungkin sudah banyak dilaksanakan oleh para pengajar sejarah, meskipun perlu dibuktikan kebenaran dan kesungguhannya.

Apabila hal itu benar, maka peserta didik diharapkan akan lebih mampu untuk memahami hakekat belajar sejarah dan sekaligus merasa terlibat dalam proses belajar sejarah. Hal itu dilakukan oleh pengajar sejarah dengan memeriksa kembali berbagai informasi dalam sumber-sumber belajar yang diandalkan (G. Moedjanto, 1999: 19).

Dalam kegiatan belajar mengajar sejarah, seorang guru harus mampu menciptakan proses belajar mengajar yang dialogis, sehingga dapat memberi peluang untuk terjadinya atau terselenggaranya proses belajar mengajar yang aktif. Dengan cara ini, peserta didik akan mampu memahami sejarah secara lebih benar, tidak hanya mampu menyebutkan fakta belaka. Pemahaman konsep belajar sejarah yang demikian, memerlukan pendekatan dan metode pengajaran yang lebih bervariasi, agar peserta didik benar-benar dapat mengambil manfaat dari belajar sejarah (Abu Suud, 1994).

Hasil belajar yang dimaksud adalah terjadinya perubahan dan perbedaan dalam cara berpikir, merasakan, dan kemampuan untuk bertindak serta mendapat pengalaman dalam proses belajar mengajar. Untuk itu, pengajaran sejarah yang bersifat destruktif sebagaimana sering dijumpai di lapangan perlu diubah. Hal ini sejalan dengan pemikiran Sartono Kartodirdjo (Sartono Kartodirdjo, 1982: 6) yang mengungkapkan bahwa: "Apabila sejarah hendak tetap berfungsi dalam pendidikan, maka harus dapat menyesuaikan diri dengan situasi sosial dewasa ini. Jika studi sejarah terbatas pada pengetahuan fakta-fakta, akan menjadi steril dan mematikan segala minat terhadap sejarah". Sependapat dengan Sartono Kartodirdjo, Ahmad Syafii Maarif mengatakan bahwa, "pengajaran sejarah yang terlalu mengedepankan aspek kognitif, tidak akan banyak pengaruhnya dalam rangka memantapkan apa yang sering disebut sebagai jati diri dan kepribadian bangsa" (Ahmad Syafii Maarif, 1995: 1). 
Lebih jauh diungkapkan pula bahwa pengajaran sejarah nasional yang antara lain bertujuan untuk mengukuhkan kepribadian bangsa dan integritas nasional sebagai bagian dari tujuan pergerakan nasional yang dirumuskan secara padat dalam sumpah pemuda 1928 diperlukan pemilihan strategi dan metode mengajar yang tepat. Aspek kognitif dan aspek moral perlu dianyam secara koherensi dan integratif, masing-masing saling menguatkan, tanpa mengorbankan watak ilmiahnya.

\section{PENUTUP}

Dalam kajian ilmiah akademis, anggapan bahwa semua manusia adalah sejarawan bagi dirinya sendiri kurang berlaku. Bahkan sejarawan tidak identik dengan ahli sejarah. Ahli sejarah adalah orang yang mengetahui banyak tentang berbagai teori dan konsep sejarah. Namun demikian ahli yang bersangkutan belum tentu menjadi sejarawan.

Aksentuasi pada ahli sejarah adalah bidang pengetahuan. Sedangkan sejarawan adalah orang yang menghasilkan karya sejarah. Aksentuasi pada sejarawan pada hasil karyanya. Orang yang menghasilkan karya sejarah walaupun yang bersangkutan bukan ahli sejarah, sebagaimana yang sering dilakukan oleh peminat sejarah (sejarah amatir) disebut sejarawan.

Dalam konsep yang semakin meluas, sejarawan, sejarah, dan pendidikan memiliki ikatan nilai dan moral, dimana satu dengan yang lainnya saling berhubungan. Karena sejarah tidak akan berguna kalau tidak dijadikan pendidikan, baik pendidikan nilai, moral, politik, penalaran, keindahan dan masa depan.

\section{DAFTAR PUSTAKA}

Abu Suud, "Format Metodologi Pengajaran Sejarah Dalam Transformasi Nilai dan Pengetahuan". Makalah Seminar Nasional 1994 IKIP Yogyakarta.

Ahmad Syafii Maarif, Keterkaitan Antara Sejarah, Filsafat, dan Agama (Yogyakarta: IKIP Yogyakarta, 1997).

Ahmad Syafii Maarif, "Historiografi dan Pengajaran Sejarah Indonesia, Makalah dalam Seminar Nasional tentang Demitologi Pemahaman Sejarah Masa Kini dalam Rangka Pendewasaan Pengetahuan Sejarah Bangsa (Padang: FPIPS IKIP Padang, 1995).

Allan C. Ornestein and Daniel U Levine, $\boldsymbol{A n}$ Introduction to the Fondations of Education, Third Edition (Boston: Houghton Mifflin Company, 1996).

Anhar Gonggong, "Nasionalisme: Tinjauan Kritis dengan Wawasan Sejarah", makalah seminar Nasional, Pengajaran Sejarah dan Nasionalisme (Yogyakarta: Jurusan Pendidikan Sejarah FPIPS IKIP Yogyakarta, 1996).

Bela H. Banatny, A A. System View of Education: Concepts and Principles for Effective Practice. (Englewood Cliffs: Educational Technology, 1992).

Dennis Gunning, The Teaching of History. (London: Cronhelm, 1999). Paulo Freirre, Politik Pendidikan: Kebudayaan, Kekuasaan, dan 
Pembebasan. Alih bahasa agung Prihantoro. (Yogyakarta: Pustaka Pelajar, 1999).

G. J. Renier. History: Its Purpose Method (New York: Herper and Row, 1995).

G. Moedjanto, "Reformasi Pengajaran Sejarah Nasional", dalam Kompas 1 Mei 1999.

Hafid Abbas, "Dasar Filosofis Kurikulum Sejarah", dalam Simposium Pengajaran Sejarah: Kumpulan Makalah Diskusi (Jakarta: Departemen Pendidikan dan Kebudayaan RI, 1998). 29

Hariyono, "Pengajaran Sejarah dan Egenwelt Subjek-Didik", dalam Historika (Surakarta: PPS UNS).

Helius Syamsudin, "Penulisan Buku Teks Sejarah: Kriteria dan Permasalahannya", Dalam Simposium Pengajaran Sejarah: Kumpulan Makalah Diskusi (Jakarta: Departemen Pendidikan dan Kebudayaan, 1998).

Husain Haikal, Tut Wuri Handayani dalam Pendidikan Sejarah: Suatu Penelitian Kepustakaan (Jakarta: PPLPTK, 1989).

Juliet Gardiner, What is History Today? (London: Macmillan, 1988).

Nugroho Notosusanto, "Teori Sejarah", dalam I Gde Widja, Pengantar Ilmu Sejarah: Sejarah dalam perspektif pendidikan (Semarang: Satya Wacana, 1989).

Kuntowijoyo, Pengantar Ilmu Sejarah (Yogyakarta: Yayasan Bintang Budaya, 1995).
Sartono Kartodirdjo, Pendekatan Ilmu Sosial dalam Metodologi Sejarah (Jakarta: PT. Gramedia Pustaka Utama, 1992).

Sartono Kartodirdjo, Pembangunan Bangsa, Nasionalisme, Kesadaran dan Kebudayaan Nasional (Yogyakarta: Universitas Gadjah Mada, 1990).

Sartono Kartodirdjo, Pemikiran dan Perkembangan Historiografi Indonesia (Jakarta: PT. Gramedia, 1982).

Sartono Kartodirdjo, Kebudayaan Pembangunan dalam Perspektif Sejarah (Yogyakarta: Gadjah Mada University Press, 1990).

Soedjatmoko, "Sejarawan Indonesia dan Jamannya", dalam Soedjatmoko, dkk., (ed), Historiografi Indonesia Sebuah Pengantar (Jakarta: PT. Gramedia Pustaka Utama, 1995).

Soedjatmoko, Dimensi Manusia dalam Pembangunan: Pilihan Karangan (Jakarta: Lembaga Penelitian, Pendidikan, dan Penerangan Ekonomi dan Sosial, 1983).

Soedjatmoko, "Kesadaran Sejarah dalam Pembangunan", dalam Prisma No. 7. Jakarta LP3ES. 30

Suyatno Kartodirdjo, "Teori dan Metodologi Sejarah dalam Aplikasinya", dalam Historika, No. 11 Tahun XII. (Surakarta: Program Pasca Sarjana Universitas Negeri Jakarta KPK Universitas Sebelas Maret Surakarta, 2000).

Taufik Abdullah, Sejarah Lokal di Indonesi: Kumpulan Tulisan (Yogyakarta: Gadjah Mada University Press, 1996). 
William H. Frederick dan Soeri Soeroto (ed). Pemahaman Sejarah Indonesia Sebelum dan Sesudah Revolusi (Jakarta: Lembaga Penelitian Pendidikan dan Penerangan dan Ekonomi Sosial, 1982).

Winata Putera US, Model-model Pembelajaran. (Jakarta: Depdikbud, 1992).

Winarno Surakhmad, Metodologi Pengajaran Nasional. Jakarta: UHAMKA, 2000.

Zamroni, Paradigma Pendidikan Masa Depan. (Yogyakarta: Bayu Indra Grafika, 2000). 